\title{
Schelling and the New England Mind
}

Joel David Stormo Rasmussen

Mansfield College, University of Oxford

Mansfield College

Mansfield Road

Oxford OX1 3TF

United Kingdom

01865282917

joel.rasmussen@theology.ox.ac.uk

\begin{abstract}
This essay examines the reception of F.W.J. Schelling's philosophy in nineteenthcentury New England principally through a consideration of three exemplary figures: the Congregationalist James Marsh (1794-1842), the Transcendentalist Ralph Waldo Emerson (1803-1882), and the Pragmatist Charles Sanders Peirce (1839-1914). It shows that although Schelling's influence on these figures was undeniable it was also mediated, highly attenuated, and generally more selective and impressionistic than critical or scholarly.
\end{abstract}

\section{Keywords}

F.W.J. Schelling; James Marsh; Ralph Waldo Emerson; Charles Sanders Peirce; Idealism; Transcendentalism

\section{Introduction}

One can read in American intellectual history for a very long time without ever encountering the name Friedrich Schelling. The idea that there is some intellectual tradition or philosophical conversation we could identify as F.W.J. Schelling's legacy or 'afterlife' in North America might seem at first blush rather dubious. Compared with G.W.F. Hegel, for example, who provided a programmatic vision to the so-called 
St. Louis Hegelians, Schelling never bequeathed his name to any 'Schellingian' school of philosophy anywhere in the United States. Was Schelling's philosophy of little consequence in America, therefore? Indeed, the scholarly perception that Schelling's influence on American philosophical currents was negligible is probably typified by Bruce Kuklick's generally excellent study entitled A History of Philosophy in America, 1720-2000, in which Schelling's name is mentioned exactly once. There, in connection with the establishment of a seminary and college of the German Reformed Church in rural Mercersburg, Pennsylvania, we read that a 25-year-old Swiss theologian named Philip Schaff who was appointed to teach theology and church history had in 1841 'heard Friedrich Schelling's lectures at Berlin and sat in the same audience with Søren Kierkegaard, Michael Bakunin, and Friedrich Engels.' Whether or not Schaff's early brush with greatness helped him to become the great scholar that he did in fact become (Schaff's eight-volume History of the Christian Church was among the great works of scholarship produced in the United States in the nineteenth century) there is no evidence that his teaching and scholarship did anything to mediate Schelling's thinking to American pupils and readers.

Yet granting that Schelling did not enter American philosophy directly via Schaff and the so-called Mercersburg Theology, his thinking nonetheless did enter indirectly via another route of reception and transmission that was no less theological, at least initially. For this story is one of both churchmen and philosophers (to use a phrase from another work by Kuklick); it is a story in which the panentheistic idealism of Schelling travels stowaway to America in a volume written 'particularly for Students intended for the Ministry' and to defend the claim that 'CHRISTIAN FAITH IS THE PERFECTION OF HUMAN REASON'; namely, it is a story in which Samuel Taylor Coleridge's Aids to Reflection played a crucial role in the transmission (and the obfuscation) of Schelling's ideas in the new world. ${ }^{2}$ Whether that transatlantic journey was judged to have brought plague or panacea depended upon the particular perspective of Coleridge's American readers. To those who affirmed strict continuity with the orthodox Calvinism of their Puritan forebears, the Romantic religion of Coleridge (let alone Schelling) was very much the former; but to those enchanted by the intuition that divinity moved in, with, and through human reason, romantic idealism was a salutary breath of fresh air. Among the latter were such post-Unitarian Transcendentalists (as they came to be called) as Frederic Henry Hedge, Bronson Alcott, Margaret Fuller, James Elliot Cabot, Henry David Thoreau 
and, most notably in this connection, Ralph Waldo Emerson. The Transcendentalists were followed in a subsequent generation by the rise of American Pragmatism as articulated variously by Charles Sanders Peirce, William James, and John Dewey, but with them too one can often see elective affinities with Schelling, and with Peirce in particular the express self-identification as a kind of 'Schellingian'.

Here at the outset, however, two caveats are in order. First, what follows is not an attempt to canvas Transcendentalist literature generally to discover quotations, allusions, or influences that might be 'Schellingian' in nature or influence, and neither does it seek to map Schelling's influence on the classical Pragmatists as a group. Rather, this essay is an examination of the transmission and creative appropriation between a few key individuals, and is therefore somewhat analogous to Emerson's own 'Representative Men’ approach. Calvinist James Marsh (1794-1842), Transcendentalist Ralph Waldo Emerson (1803-1882), and Pragmatist Charles Sanders Peirce (1839-1914) are all representative individuals of different aspects of 'the New England Mind' and can be regarded as exemplary figures in an inevitably partial reconstruction of over-lapping sets of historically influential conversations. Second, it is probably best to make clear from the beginning that Schelling's influence upon these figures is mediated and attenuated; where Schelling's influence seems discernible to those who have eyes to see (as in the case with Emerson), it usually goes unacknowledged. And even where an intellectual debt is expressly acknowledged (as it was by Peirce), the appropriation nonetheless often seems more selective and impressionistic than critical or scholarly.

\section{James Marsh and Aids to Reflection}

The 'New England Mind' was the phrase historian Perry Miller used to characterize the amalgamation of piety, idealism, heroism, snobbery and, indeed, sometimes cruelty characteristic of Puritan life and thought from the earliest days of the Massachusetts Bay Colony. 'Surely most of the first settlers of New England had it; in later generations most of those who did not have it pretended to it. It blazed most clearly and fiercely in the person of Jonathan Edwards', but Miller writes that likewise 'Emerson was illuminated, though from afar, by its rays'. ${ }^{3}$ Less well known than either Edwards or Emerson, but still hugely important for the introduction of 
German thought into America, was the Vermont Calvinist James Marsh. As a Congregationalist clergyman and President of the University of Vermont, Marsh was concerned to find philosophical support for Trinitarian orthodoxy, and thus resist the 'injurious and dangerous tendency' of Lockean empiricism that had arisen across the eighteenth century. ${ }^{4} \mathrm{He}$ believed he found this support in Coleridge's 1825 work Aids to Reflection, and in 1829 Marsh published an American edition of the work with a long 'Preliminary Essay' that, as Louis Menand notes, turned out to be 'one of the originary texts of American Transcendentalism., ${ }^{5}$

In his 'Preliminary Essay', Marsh sought to introduce Coleridge's work to his students and other readers, and in this respect his influence on future developments on the American scene was significant in its own right. Here Marsh emphasized what he took to be the Kantian heart of Aids to Reflection, namely, that the key to Coleridge's thinking is found in the distinction he makes between Nature and Free-will, and the distinction between Understanding and Reason. The Understanding is the cognitive faculty by which knowledge of the visible, sensible world is gained; it is the "the faculty of the finite', as Coleridge called it, in contrast to the faculty of Reason, which is the 'faculty of the infinite'. Reason alone is regarded as the intuitive power that can enable the earnest seeker to apprehend the transcendent truth of Spirit. This distinction between the faculties of understanding and reason are supposed to have correlated with Immanuel Kant's distinction between Verstand and Vernunft. But they don't exactly. Kant himself never wished to deny empiricism's distinction between sensible things we can perceive and know conceptually, and purportedly supersensible things that we cannot know; what he wanted was to improve upon empiricism by elucidating the conditions for the possibility of knowing what we know. More precisely, while Coleridge and Marsh's faculty of Understanding corresponds more or less strictly to Kant's Verstand, their conception of Reason as an intuitive power capable of grasping noumenal truths transgresses the boundaries of Reason and knowledge that Kant believed he had delimited for Vernunft. Marsh's interpretation was a 'mistake', according to Menand, although it was one that closely followed Coleridge. ${ }^{6}$ Rosemary Ashton gives voice to a typical Kantian critique of this 'mistake' when she writes that it is 'a debasing of Kant's carefully built-up system. ${ }^{, 7}$ Yet, as Nicholas Boyle responds, 'this debasing, if such it is, is closely paralleled in contemporary German philosophy' where figures such as Fichte, Hegel, 
Hölderlin, and Schelling all gave 'a similar role to the Ideas of Reason ... thus broadening the scope of the faculty whose pretensions Kant had sought to rein in. ${ }^{8}$

The parallel Boyle notes is by no means merely coincidental, and this early Romantic project of 'broadening the scope' of reason was not carried out in isolation. Not only were the early German Romantics reading Kant and each other, but Coleridge — virtually alone among Anglophones in this regard initially—was reading them too. And for Coleridge, there can be little doubt that Schelling was the most important among these possible German influences. While Coleridge's reading of Schelling was creative and thus never merely derivative (as Douglas Hedley has shown, it was not Coleridge's intention merely 'to translate Schelling into English'9), the signal importance of Schelling for Coleridge is well documented in secondary literature, and even attested by Coleridge himself. ${ }^{10}$ As he wrote in his 1817 Biographia Literaria, in Schelling 'I first found a genial coincidence with much that I had toiled out for myself, and a powerful assistance in what I had yet to do. ${ }^{11}$ And when in Aids to Reflection he asserted that 'Reason indeed is far nearer to SENSE than to Understanding' Coleridge was affirming - in disagreement with Kant but complete agreement with Schelling - that reason possesses the capacity for intellectual intuition analogous to the intuitions of the senses. ${ }^{12}$ Thus, when in his 'Preliminary Essay' to Aids to Reflection Marsh underscored Coleridge's distinction between understanding and reason, he believed he was elucidating an English translation of the implications of Kant's thought for Christian reflection. In fact, however, he was mediating Coleridge's creative appropriation of Schelling's objective idealism. ${ }^{13}$ In any case, 'Marsh provided Emerson and his friends with an alternative to the Unitarianism and empiricism they were trying to renounce', as Menand writes - 'He helped bring Romanticism to America., ${ }^{, 14}$

\section{Schelling and Emersonian Transcendentalism}

Despite the convoluted compositional history of the American edition of Aids to Reflection, the consequence for American thought of Marsh's misunderstanding of Coleridge's mistranslation of Schelling's sublation of Kant's critical philosophy is clear from Emerson's brief account of the proximate source of the 'new views' on American shores. In a lecture entitled 'The Transcendentalist' delivered in Boston in 
1842 - scarcely a decade after Marsh published his edition-Emerson contrasted materialist and idealist worldviews broadly and averred:

It is well known to most of my audience that the Idealism of the present day acquired the name of Transcendental, from the use of that term by Immanuel Kant, of Konigsberg, who replied to the sceptical philosophy of Locke, which insisted that there was nothing in the intellect which was not previously in the experience of the sense, by showing that there was a very important class of ideas, or imperative forms, which did not come by experience, but through which experience was acquired; that these were intuitions of the mind itself; and he denominated them Transcendental forms. ${ }^{15}$

While Emerson believed Transcendentalism is perennial, and thus it did not originate with Kant or anyone else, he at this point at least believed Transcendentalism was broadly consistent with Kant in the notion that reason yields intuitive knowledge of truths that transcend phenomena. But that he was already more in line with Schelling than with Kant is clear from his declaration in the same address that 'Mind is the only reality, of which men and all other natures are better or worse reflectors. ${ }^{16}$ And that he came to this position largely via Marsh's Coleridge is evident from his declaration in his Harvard Divinity School Address (1838) that 'There is no doctrine of Reason which will bear to be taught by the Understanding. ${ }^{17}$ It would seem that the provenance of Emerson's psychological terminology here is evidently clear.

It would be a vast oversimplification, however, to suggest that his Transcendentalism is 'Schellingian' in any straightforward sense that term might connote, or indeed to ignore the fact that Emerson was drawing creatively on any number of other sources as he developed his view. For, as he was reacting against the empiricism and externalism of the Enlightenment Unitarianism of his youth, Emerson developed his conception of a universal 'Over-Soul' manifested in and through each thinking person's reason not only from the Coleridgean version of Schelling, but also from his reading of earlier Neo-Platonism, from early English translations of Brahmanic texts from India, and who knows where else. Moreover, while the history of transmission sketched above is accurate in broad outline, it should nonetheless not be taken to suggest that Emerson's only encounter with Schelling's idealism was mediated via Coleridge. In fact, in an 1831 journal entry Emerson wrote approvingly of Schelling himself, crediting him with the dictum, 'Some minds think about things; others think the things themselves. ${ }^{18}$ Emerson certainly does not find the lines in Aids 
to Reflection. But neither did he find them by reading Schelling. René Wellek tracks the phrase down to something Emerson would have encountered in a volume he was then reading entitled Guesses at Truth (1827) by Augustus William and Julius Charles Hare, and he also relates that 'a little later, Emerson became interested in De Quincey's attacks on Coleridge for his plagiarisms from Schelling, and thus found the source of many ideas in Coleridge which had attracted him profoundly. ${ }^{19}$ So if at first Emerson and others in his circle believed Kant was the guiding light of modern idealism, he soon learned that Schelling was the real seer of post-Kantian German philosophy.

From there, Emerson's interest in Schelling grew. In 1842, Emerson took over from Margaret Fuller the role of editor of The Dial, the journal of the Transcendentalists: 'Let there be rotation in martyrdom', he wrote to Fuller, when she decided she could no longer carry out that role. ${ }^{20}$ In that same year, Emerson received news from Charles Stearns Wheeler, a friend from Emerson's Harvard days then studying in Germany, that Schelling had been invited to succeed Hegel as professor in philosophy at Berlin. The very first issue of The Dial published under Emerson's leadership then included a new section dedicated to news from Berlin in which 'the main item' announced that Schelling had been invited to lecture on 'the philosophy of Revelation as an offset to the Hegelians. ${ }^{21}$ In the January 1843 issue of The Dial, Emerson included a translation by Frederic Hedge of Schelling's inaugural lecture. ${ }^{22}$ But it was not until 1845, according to Richardson, that through his direct reading Emerson 'began to grasp the importance of Schelling', for it was in 1845 that Emerson's friend James Elliot Cabot lent him his unpublished translation of Schelling's 1809 Philosophical Enquiries into the Nature of Human Freedom. ${ }^{23}$ Emerson was impressed. He wrote to tell Cabot that 'this admirable Schelling, which I have never fairly engaged with until last week, demands the "lamp" and the "lonely tower" and a lustrum of silence. I delight in his steady inevitable eye, and the breadth of his march including and disposing of so many objects of work'; yet later, after keeping Cabot's manuscript for almost a full year, Emerson apologized for being so 'ill a reader of these subtle dialectics' that in the end, he confessed, he decided to 'let it alone. ${ }^{24}$

By his own admission, then, the impression Schelling made upon Emerson was more impressionistic than scholarly. But this is of course entirely in keeping with Emerson's notion of 'The American scholar', as envisioned in his 1837 oration of the 
same name. There Emerson declared, in what Oliver Wendell Holmes, Sr. called America's intellectual declaration of independence, 'We have listened too long to the courtly muses of Europe' and, he maintained, 'Genius is always sufficiently the enemy of genius by over influence. ${ }^{25}$ And in another passage: 'One must be an inventor to read well. As the proverb says, 'he that would bring home the wealth of the Indies, must carry out the wealth of the Indies.' There is then creative reading as well as creative writing. ${ }^{26}$ Here we might well see in Emerson's vision of the scholarly life more a precursor to Harold Bloom's theory of poetry (as sketched in The Anxiety of Influence) than anything that accords with Wissenschaft. Yet Schelling — who famously moved through three different philosophical positions across his career - would surely have been sympathetic to Emerson's advocacy of a willingness to rethink one's views independent of purported authorities or even one's own precedent. And with respect to Hegel's snide remark that the protean Schelling conducted his own education in public, one can only imagine Schelling would have appreciated Emerson's quip that 'A foolish consistency is the hobgoblin of little minds, adored by little statesmen and philosophers and divines. ${ }^{27}$

In any case, even if Emerson's reading of Schelling was creative, surely intellectual influence can flow through such reading as much as by careful scholarship (perhaps even more so in some cases). But this recognition does mean that identifying the specific inlets of influence is equally impressionistic and creative, since Emerson as a rule does not quote or even cite his sources. In order to attempt such 'creative reading', however, it will be helpful first to sketch some relevant features of Schelling's Freiheitsschrift since, as we have seen, that is Schelling's only work with which Emerson was directly familiar.

In Philosophical Inquiries into the Nature of Human Freedom Schelling sought to correct the determinism of his previous 'Spinozism' with an emphasis upon divine and human freedom that he found in Jakob Böhme's theology. Böhme's thought enabled Schelling to retain the panentheistic view that human existence is 'not outside God but in God, and that man's activity itself belongs to God's life', yet at the same time affirm that 'God can only reveal himself in creatures who resemble him, in free, self-activating beings. ${ }^{28}$ Divine freedom and human freedom are thus reciprocally constituted, although asymmetrically so, since human freedom is contingent freedom whereas divine freedom is primordial. Human existence grounds ultimately in God, while God's reality is grounded solely in the primordial dialectic of 
God's own internal potencies: 'The essence of the basis [Grund], or of existence, can only be precedent to all basis [Urgrund], that is, the absolute viewed directly, the groundless [Ungrund]. ${ }^{29}$ Schelling thus envisaged divine reality to be freely selfgenerated in triadic relationality, and this he took to be the abstract metaphysical explication of Christian Trinitarian theology. 'There is born in God himself', he wrote, 'the first stirring of divine Being.... God sees himself in his own image ... the God-begotten ... and the eternal Spirit which feels within it the eternal Logos and the everlasting longing. This Spirit ... utters the Word which then becomes creative and omnipotent Will ... which informs nature. ${ }^{30}$ The divine Word, on this view, makes reality not only actual, but also meaningful; in the processes of nature generally, meaning is implicit, but in human nature, meaning becomes historically explicit. And this is because 'only in man is the Word completely articulate, which in all other creatures was held back and left unfinished. But in articulate Word the spirit reveals itself, that is God as existing, in act. ${ }^{31}$ Thus, according to Schelling, while the divine primordial essence is eternally immutable, God's Trinitarian consequent existence is historically dynamic-God undergoes contingency, suffering, and transformation. 'God is a life', Schelling attested, 'not a mere being. All life has a destiny and is subject to suffering and development. God freely submitted himself to this too, in the very beginning, when, in order to become personal, he divided light and the world of darkness. For being is only aware of itself in becoming. ${ }^{32}$ In this way, Schelling refined the Identitätsphilosophie he initially developed in conversation with Baruch Spinoza and J.G. Fichte to develop a personalist metaphysics in which the actuality of nature manifests divine self-actualization, and human freedom reveals the meaningfulness of divine freedom.

By contrast with Schelling, Emerson was a lapsed Unitarian, not a Trinitarian, and he would not say Christian theology reflected God's self-knowledge anymore than some other theological scheme-Brahmanism, say. Yet there is much here with which he seems to have resonated strongly. For example, the oft-quoted line from Emerson's 1849 'Nature' echoes Schelling's notion that human existence is 'not outside but in God':

Standing on the bare ground,- - my head bathed by the blithe air, and uplifted into infinite space, - all mean egotism vanishes. I become a transparent eyeball; I am nothing; I see all; the currents of the universal Being circulate through me; I am part or particle of God. ${ }^{33}$ 
Similarly, Emerson recapitulates Schelling's view that rational human activity 'belongs to God's life' when he says of the universal soul, 'it is not mine, or thine, or his, but we are its. ${ }^{34}$ And he channels Schelling's view that only in human beings 'is the Word completely articulate' with the pleonasm, 'Good writing and brilliant discourse are perpetual allegories. This image is the blending of experience with the present action of the mind. It is proper creation. It is the working of the Original Cause through the instruments he has already made. ${ }^{35}$

And neither are these correspondences isolated to the essay 'Nature'. In 'The Over-Soul' (1847) Emerson repeats Schelling's claim that God discloses divinity in and through the consciousness of human freedom with his assertion that we should 'distinguish the announcements of the soul, its manifestations of its own nature, by the term Revelation. These are always attended by the emotion of the sublime. For this communication is an influx of the Divine mind into our mind. ${ }^{36}$ And in 'SelfReliance' (1847) he seemingly glosses Schelling's view that 'being is only aware of itself in becoming' with his memorable line, 'Life only avails, not the having lived. ${ }^{37}$

Such examples could be multiplied. But instead of listing further passages echoing Schelling, we should turn finally to an instance where Emerson actually cites Schelling expressly in one of his essays. Fifteen years after he toiled with Cabot's translation of the Freiheitsschrift, Emerson penned an essay in 1860 he entitled 'Fate' (ironically enough) in which he quotes from Schelling's reflections on human freedom. There he writes:

It was a poetic attempt to lift this mountain of Fate, to reconcile this despotism of race with liberty, which led the Hindoos to say, 'Fate is nothing but the deeds committed in a prior state of existence.' I find the coincidence of the extremes of eastern and western speculation in the daring statement of Schelling, "that there is in every man a certain feeling, that he has been what he is from all eternity, and by no means became such in time.' To say it less sublimely, - in the history of the individual is always an account of his condition, and he knows himself to be a party to his present state. ${ }^{38}$

What does Emerson see in Schelling here? He recognizes that freedom for Schelling looks to be a matter of unfolding in time one's eternal self-determination, wherein each individual is (potentially, at least) a derivative vice-creator to God's eternal creativity. (One might think here also of Coleridge's notion of 'primary Imagination' as 'the living power and prime agent of all human perception, and as a repetition in 
the finite mind of the eternal act of creation in the infinite I AM. ${ }^{39}$ ) Yet while Emerson acknowledges Schelling's daring insight in the Freiheitschrift, in this fateschrift Emerson places the accent differently. Schelling's inquiry emphasizes what a human being can do (freedom) and considers the task of becoming in time what one always already is to be a kind of eternal self-predestination; Emerson seizes on the fact that such freedom is not absolute, but is always constrained by nature and historical context, and thus he emphasizes the negative power that limits us (necessity). 'Once we thought, positive power was all', he writes. 'Now we learn, that negative power, or circumstance is half. ${ }^{40}$ Schelling, of course, recognized this as well, and in his way said as much: 'The intelligible being, therefore, insofar as it acts absolutely and with full freedom, can as certainly only act according to its own inner nature. Or the activity can follow from its inner nature only in accordance with the law of identity, and with absolute necessity which is also the only absolute freedom.' 41

Accordingly, Schelling and Emerson can be read to hold compatible views concerning freedom and necessity, although each expresses the view somewhat differently and with distinctive emphases. Schelling emphasizes primordial determination; Emerson emphasizes specific historical circumstances. But in the end both 'hazard the contradiction,- - freedom is necessary. ${ }^{42}$ Whether Emerson came to this view primarily via Schelling's influence and the philosophical movement of idealism more generally, from his reading of the literature of India, from reinterpreting the theology of his Calvinist forebears or, more plausibly, from his personal reflection on the confluence of these and still other influences, he never tells us. Whatever the influences, Emerson found it necessary to make them flow in his own channels. And this was because for Emerson, as he himself wrote, 'imitation is suicide. $^{43}$

\section{Peirce and Schelling-fashioned Idealism}

While Emerson seems to have been resolutely cagey about acknowledging Schelling's influence on his thinking, another eminent New England mind was remarkably forthcoming, if also somewhat sardonic, about his true metaphysical colours. In an 1892 essay entitled 'The Law of Mind', Charles Sanders Peirce - a 
logician, metaphysician, and scientist generally credited as the founder of American Pragmatism — opened by writing:

I have begun by showing that tychism [from the Greek for 'chance'] must give birth to an evolutionary cosmology, in which all the regularities of nature and of mind are regarded as products of growth, and to a Schelling-fashioned idealism which holds matter to be mere specialized and partially deadened mind. I may mention, for the benefit of those who are curious in studying mental biographies, that I was born and reared in the neighborhood of Concord - I mean in Cambridge - at the time when Emerson, Hedge, and their friends were disseminating the ideas that they had caught from Schelling, and Schelling from Plotinus, from Boehm, or from God knows what minds stricken with the monstrous mysticism of the East. But the atmosphere of Cambridge held many an antiseptic against Concord transcendentalism; and I am not conscious of having contracted any of that virus. Nevertheless, it is probable that some cultured bacilli, some benignant form of the disease was implanted in my soul, unawares, and that now, after long incubation, it comes to the surface, modified by mathematical conceptions and by training in physical investigations. ${ }^{44}$

But although Peirce was happy to acknowledge the benignant influence of Schelling (via Emerson) on his thinking, he nevertheless very rarely mentioned him in his writing, and Peirce's idiosyncratic invention of a host of neologisms makes it more difficult than it was with Emerson to discover clear parallels with, or obvious allusions to, Schelling's writings. It is notable, however, that two respects in which Peirce hewed closer to Schelling's idealism than Emerson did was in his dogged commitment to thinking in triadic forms, and in his view that one's Weltanschauung should not be primarily poetic but scientific.

Aside from teaching philosophy at Johns Hopkins University for a few years, Peirce earned his living not as a professional academic but instead (when not living in poverty) by working as a scientist for the United States Coast and Geodetic Survey. The consequence for philosophy of his training as an experimental scientist was his insight that most previous metaphysicians misunderstood the genuinely hypothetical nature of metaphysical claims. Kant and Hegel, for example, sought to articulate 
apodictic demonstrations of knowledge. Peirce, by contrast, proposed an understanding of speculative metaphysics consonant with the spirit of modern scientific experimentation. And in this spirit, metaphysics was to begin not with first principles (such as that of non-contradiction, dialectical logic, or causal determinism) but in wonder. Wonder, namely, as to why there is something rather nothing to wonder about; wonder that there is order in the universe, since if there were only chaos there would be no wonderers, and indeed nothing at all about which to wonder. Accordingly, for Peirce the task of metaphysics was to propose a general hypothetical account of how the universe evolves from chaos to order:

Metaphysics has to account for the whole universe of being. It has, therefore, to do something like supposing a state of things in which that universe did not exist, and consider how it could have arisen. However, this statement needs amendment. For time is itself an organized something, having its law or regularity; so that time itself is part of the universe whose origin is to be considered. We have therefore to suppose a state of things before time was organized. Accordingly, when we mean to speak of the universe as 'arising' we do not mean that literally. We mean to speak of some kind of sequence, say, an objective logical sequence; but we do not mean in speaking of the first stages of creation before time was organized, to use 'before,' 'after,' 'arising,' and such words in the temporal sense. ${ }^{45}$

In accordance with this notion of the universe 'arising', Peirce suggested that we envision reality itself on an evolutionary model that classifies things into three simple but general categories of 'Firstness', 'Secondness', and 'Thirdness'. ${ }^{46}$ The categories themselves are abstractions, but nonetheless real for that fact. As Paul Franks has shown, the main reason Peirce can call himself 'a Schellingian, of some stripe ${ }^{47}$ is because of their shared 'conviction that the only adequate realism is a realism about ideas that is at the same time an objective idealism - in particular, a realistic idealism committed to the evolution of ideas in and through the development of natural organization. ${ }^{48}$ With Schelling and against all nominalists (and incidentally he once stated that he thought all modern philosophers except Schelling were nominalists ${ }^{49}$ ), Peirce asserted that 'the one intelligible theory of the universe is that of objective idealism, that matter is effete mind. ${ }^{50}$ Said another way, with Schelling and against all 
philosophers who think reason is merely the capacity of finite human beings for thinking, 'mind' is the objective, evolving structure of the universe.

As for the three categories themselves: 'First is the conception of being or existing independent of anything else. Second is the conception of being relative to, the conception of reaction with, something else. Third is the conception of mediation, whereby a first and second are brought into relation'; 'Chance is First, Law is Second, Evolution is Third. ${ }^{51}$ Peirce then nested within this vague set of categories the general features of evolution he called 'chance', 'necessity', and 'continuity', and again in another comparatively more specific iteration of neologisms, 'tychasm', 'ananchasm', and 'agapasm'. 52 Tychasm indicates the spontaneity of chance in firstness; ananchasm refers to the element of necessity that orders the universe without eliminating spontaneity; and agapasm expresses the element of growth in continuity that gives final purpose to the order of things. Viewed synoptically, Peirce proposed that the universe is best conceived as a dynamic interplay between these features in a process he called 'evolutionary love'. 53

Anthropomorphizing though it might be, Peirce's appeal to evolutionary love was not gratuitous. The failing of Darwinian evolution, he maintained, as with the Social Darwinism that was typical of the age, was that it universalized greed and precluded any role for genuine love. ${ }^{54}$ Equally, the 'fatal disease' of Hegel's philosophy was that it collapsed thirdness into secondness, with the consequence that it conceived dialectical mediation in terms of universal necessity, and thereby precluded any role for genuine novelty and freedom. ${ }^{55}$ It was not ultimately the social-political consequences alone that led Peirce to reject Darwinism and Hegelianism, however, but rather the fact that neither of these worldviews offered any way to account for the element of purpose interwoven with chance and necessity across cosmic history. By contrast, Peirce's conception of evolutionary love is expressly purposeful: 'Love, recognizing germs of loveliness in the hateful, gradually warms it into life and makes it lovely. ${ }^{56}$ According to Pierce, love is the final cause of evolution-live is that which gives structure and purpose to the law of mind. In this view he resonates strongly with Schelling, for whom love is the appropriate characterization of the animating principle and telos of rationality: 'On the one hand, philosophy receives its name from love, as the general inspiring principle, on the other hand, from this original wisdom which is her genuine goal. ${ }^{, 57}$ 
Equally, just as for Schelling all principles ground ultimately in God, for Peirce too the identification of love as the final cause of evolution, and the conception of evolution itself as the dynamic process of universal history, ineluctably returns one to the question concerning God's reality. 'A genuine evolutionary philosophy', he wrote in 1891, 'that is, one that makes the principle of growth a primordial element of the universe, is so far from being antagonistic to the idea of a personal creator, that it is really inseparable from that idea. ${ }^{58}$ We should not take this to mean, however, that Peirce (anymore than Schelling) believed the reality of God could be demonstrated conclusively. Rather, as he argued in his 1908 article entitled 'A Neglected Argument for the Reality of God', reflection ('musement') on the evolving order of the 'three universes' of mere ideas, brute actuality, and the power to establish connections between ideas and actuality provides grounds for a living hypothesis concerning God's existence: 'in the Pure Play of Musement the idea of God's Reality will be sure sooner or later to be found an attractive fancy, which the Muser will develop in various ways. The more he ponders it, the more it will find response in every part of his mind, for its beauty, for its supplying an ideal of life, and for its thoroughly satisfactory explanation of his whole threefold environment. 59

Despite the resolutely triadic character both of his metaphysics generally and of his argument for God's reality specifically, however, Peirce nevertheless ultimately left the relationship between his metaphysics and his theology ambiguous. It might seem tempting to characterize both his theology and his metaphysics as equally 'Schellingian, of some stripe', but Peirce seemed genuinely reluctant to identify God and the purposefully evolving universe in any way that would naturalize the divine or deify the world. The relationship seems finally to be an analogical one, as evidenced by his remark that 'a purpose essentially involves growth, and so cannot be attributed to God. Still it will, according to the hypothesis, be less false to speak so, than to represent God as purposeless ${ }^{, 60}$ Furthermore, because the objective of the 'Neglected Argument' was not to explain God in terms of his categories, but rather to explain the coinherence of the 'three universes' through the hypothesis of God as their creator, Peirce would readily have acknowledged that God is an exception to his categories, even while the logical structure of the belief in God exemplifies his categories. ${ }^{61}$ Yet in any case, Peirce never attempted to characterize the primordial character of the Godhead, as Schelling did. And in this respect, while we can recognize the broad outlines of Schelling's influence on Peirce's objective idealist metaphysics, Peirce 
nevertheless ultimately proved unwilling to follow Schelling in his Trinitarian theological speculation.

\section{Conclusion}

Schelling's afterlife in America haunts like a genial ghost, undetected by most, but discernible in spectral outline for those who have eyes to see. He haunts subtextually in Marsh's edition of Coleridge's Aids to Reflection, privately to initiated Transcendentalists via Cabot's unpublished translation of the Freiheitschrift, cryptically through Emerson's 'creative reading', and expressly as a metaphysical fellow traveller in Peirce's objective idealism. None of these eminent New England minds spilled any ink on careful criticism of Schelling's writings, and they took from him only what suited the development of their own philosophical and religious visions. But they read him in quiet hours, and found in his metaphysics a heartening aid to reflection in articulating their own distinctively American conceptions of the law of Mind.

\section{Note on Contributor}

Joel D. S. Rasmussen is Associate Professor in the Faculty of Theology and Religion at Oxford University, and a Fellow of Mansfield College, Oxford. He is the author of Between Irony and Witness: Kierkegaard's Poetics of Faith, Hope, and Love (2005), and co-editor of William James and the Transatlantic Conversation (2014) and The Oxford Handbook of Nineteenth-Century Christian Thought (2017). 


\section{Notes}

1. Kuklick, Philosophy in America, 89.

2. Coleridge, Aids to Reflection, 1x; Marsh, 'Preliminary Essay', xiv.

3. Miller, The New England Mind, 5.

4. Marsh, "Preliminary Essay", xxviii.

5. Menand, The Metaphysical Club, 247.

6. Ibid., 263.

7. Ashton, The German Idea, 47.

8. Boyle, 'General Introduction', 23.

9. Hedley, Coleridge, Philosophy and Religion, 290.

10. See, for example Wellek, History of Modern Criticism. 2.156, and Fruman, Coleridge, The Damaged Archangel, 211-14. Hedley (Coleridge, Philosophy and Religion, 33) makes clear that Coleridge 'could not have known the full-blown natural theology of Schelling ... but only fragments and outlines - of which Schelling's Philosophie und Theologie, Vorlesungen über die Methode des akademischen Studiums, Bruno, and the Freiheitsschrift were the most significant.'

11. Coleridge, Biographia Literaria 1.160; See also Hedley, Coleridge, Philosophy and Religion, 34.

12. Coleridge, Aids to Reflections, 142.

13. Hedley (Coleridge, Philosophy and Religion, 68) glosses Schelling's objective idealism in the following way: 'Objective idealism means that reason (or Vernunft) is thought of as an objective structure rather than as the capacity of finite beings for thinking. It is a philosophy of absolute subjectivity because 'the I contains all Being, all Reality' ('das Ich enthällt alles Sein, alle Realität'). Schelling combines the concept of being with that of self-consciousness. The issue of the nature of being should be explained with recourse to the principle of self-consciousness. The terminological connection between being and self-consciousness arises with German Idealism in the period of the Jacobi-Spinoza discussion. God is, in the tradition and spirit of Aristotle, absolute reflection: self-affirmation. Furthermore, true philosophy is theology because God is the highest object of philosophy.'

14. Menand, The Metaphysical Club, 248.

15. Emerson, Ralph Waldo Emerson, 101-2.

16. Emerson, Ibid., 98. See also Emerson's apparently Schellingian view of intuition as primary wisdom: 'The inquiry leads us to that source, at once the essence of genius, of virtue, and of life, which we call Spontaneity or Instinct. We denote this primary wisdom as Intuition, whilst all later teachings are tuitions. In that deep force, the last fact behind which analysis cannot go, all things find their common origin.' Ibid.,13940 .

17. Ibid., 57. Compare Emerson's statement in 'Nature' (1849) that all experience educates 'both the Understanding and the Reason. Every property of matter is a school for the understanding,- - its solidity or resistance, its inertia, its extension, its figure, its divisibility. The understanding adds, divides, combines, measure, and finds nutriment and room for its activity in this worthy scene. Meantime, Reason transfers all these lessons into its own world of thought, by perceiving the analogy that marries Matter and Mind.' Ibid., 18.

18. Emerson, Journals and Miscellaneous Notebooks, 6.195.

19. Wellek, Confrontations, 198. 
20. Quoted in Richardson, Emerson, 370.

21. Richardson, Emerson, 378.

22. The Dial, 3, no. 3 (1843) 398-404. See also Bauschinger, The Trumpet of Reform, 49.

23. Richardson, Emerson, 406.

24. Quoted in Wellek, Confrontations, 199.

25. Emerson, Ralph Waldo Emerson, 41.

26. Ibid., 42.

27. Ibid., 137. For the context of Hegel's remark, see Pinkard, German Philosophy, 172.

28. Schelling, Inquiries into Human Freedom, 11, 19.

29. Ibid., 88-9.

30. Ibid., 35-6.

31. Ibid., 39.

32. Ibid., 84.

33. Emerson, Ralph Waldo Emerson, 6.

34. Ibid., 13.

35. Ibid., 15.

36. Ibid., 158.

37. Ibid., 142.

38. Ibid., 349-50. The larger passage from which Emerson quotes reads as follows:

'In original creation, as has been shown, man is an undetermined entity (which may be mythologically presented as a condition antecedent to this life, a state of innocence and of initial bliss). He alone can determine himself. But this determination cannot occur in time; it occurs outside of time altogether and hence it coincides with the first creation even though as an act differentiated from it. Man, even though born in time, is nonetheless a creature of creation's beginning (the centrum). The act which determines man's life in time does not itself belong in time but in eternity. Moreover, it does not precede life in time but occurs throughout time (untouched by it) as an act eternal by its own nature. Through it man's life extends to the beginning of creation, since by means of it he is also more than creature, free and himself eternally beginning. Though this idea may seem beyond the grasp of common ways of thought, there is in every man a feeling which is in accord with it, as if each man felt that he has been what he is from all eternity, and had in no sense only come to be so in time.' Schelling, Philosophical Inquiries into the Nature of Human Freedom, 63-64.

39. Coleridge, Biographia Literaria, 2.202.

40. Emerson, Ralph Waldo Emerson, 350.

41. Schelling, Inquiries into Human Freedom, 62.

42. Emerson, Ralph Waldo Emerson, 354.

43. Ibid., 132

44. Peirce, Collected Papers, 6.102).

45. Ibid., 6.214

46. Ibid., 8.327-79; 1.203-414.

47. Ibid., 6.605 .

48. Franks, 'Peirce's "Schelling-Fashioned Idealism", 751. In this essay, Franks also elucidates deep resonances between Peirce's philosophy and Lurianic kabbalah, which he demonstrates was a source for Schelling's own objective idealism.

49. Peirce, Collected Papers, 1.21.

50. Ibid., 6.605 . 
51. Ibid., 6.25-6.

52. Ibid., 6.302.

53. Ibid., 6.287-317.

54. Ibid., 6.293-4.

55. Ibid., 8.268.

56. Ibid., 6.289 .

57. Schelling, Investigations into Human Freedom, 76.

58. Peirce, Collected Papers, 6.157.

59. Ibid., 6.465 .

60. Ibid., 6.466 .

61. Neville, The Highroad around Modernism, 49.

\section{Bibliography}

Ashton, Rosemary. The German Idea: Four English Writers and the Reception of German Thought 1800-1860. Cambridge: Cambridge University Press, 1980.

Bauschinger, Sigrid. The Trumpet of Reform: German Literature in Nineteenthcentury New England. Translated by Thomas S. Hansen. Columbia, SC: Camden House, 1998.

Boyle, Nicholas. 'General Introduction: the Eighteenth and Nineteenth Centuries.' In Philosophy and Natural Sciences. Vol. 1 of The Impact of Idealism: The Legacy of Post-Kantian German Thought. Edited by Nicholas Boyle, Liz Disley, and Karl Ameriks. Cambridge: Cambridge University Press, 2013.

Coleridge, Samuel Taylor. Aids to Reflection, in the Formation of a Manly Character. Edited by James Marsh. Marsh, James. Burlington, VT: Chauncey Goodrich, 1829.

Coleridge, Samuel Taylor. Biographia Literaria. 2 vols. Edited by J. Shawcross.

Oxford: Oxford University Press, 1973.

Emerson, Ralph Waldo. The Journals and Miscellaneous Notebooks of Ralph Waldo Emerson. 16 vols. Edited by William H. Gilman, Alfred R. Ferguson, George P. Clark, and Merrell R. David. (Cambridge, MA: Harvard University Press, 1966.

Emerson, Ralph Waldo. Ralph Waldo Emerson. Edited by Richard Poirier. Oxford: Oxford University Press, 1990.

Franks, Paul. 'Peirce's "Schelling-Fashioned Idealism" and "the Monstrous Mysticism of the East"'. British Journal for the History of Philosophy, 23, no. 4 (2015): 732-755.

Fruman, Norman. Coleridge, The Damaged Archangel. New York: Braziller, 1971. 
Hedley, Douglas. Coleridge, Philosophy and Religion: Aids to Reflection and the Mirror of the Spirit. Cambridge: Cambridge University Press, 2000.

Hedge, Frederic Henry. 'Schelling's Introductory Lecture in Berlin, 15 November, 1841' The Dial 3, no. 3 (1843) 398-404.

Kuklick, Bruce. A History of Philosophy in America, 1720-2000. Oxford: Oxford University Press, 2001.

Marsh, James. 'Preliminary Essay', in Samuel Taylor Coleridge, Aids to Reflection, in the Formation of a Manly Character. Burlington, VT: Chauncey Goodrich, 1829).

Menand, Louis. The Metaphysical Club: A Story of Ideas in America. New York: Farrar, Straus and Giroux, 2001.

Miller, Perry. The New England Mind: The Seventeenth Century. New York: Macmillan, 1939.

Neville, Robert Cummings. The Highroad Around Modernism. Albany: State University of New York Press, 1992.

Peirce, Charles Sanders. Collected Papers of Charles Sanders Peirce. 8 vols. Edited by Charles Hartshorne and Paul Weiss. Cambridge, MA: Harvard University Press, 1931-5.

Pinkard, Terry. German Philosophy, 1760-1860: The Legacy of Idealism. Cambridge: Cambridge University Press, 2002.

Schelling, Friedrich. Philosophical Inquiries into the Nature of Human Freedom, Tranlated by James Gutman. Chicago: Open Court, 1936.

Wellek, René. A History of Modern Criticism: 1750-1950. 2 vols. New Haven: Yale University Press, 1955.

Wellek, René. Confrontations: Studies in the Intellectual and Literary Relations between Germany, England, and the United States during the Nineteenth Century. Princeton: Princeton University Press, 1965. 